\title{
XIII. Observations on ants, and on the poison of these insects; with some hints for destroying them
}

\section{Amoureux jun. M.D.}

To cite this article: M. Amoureux jun. M.D. (1800) XIII. Observations on ants, and on the poison of these insects; with some hints for destroying them , Philosophical Magazine Series 1, 7:26, 152-157, DOI: $10.1080 / 14786440008562569$

To link to this article: http://dx.doi.org/10.1080/14786440008562569

曲 Published online: 18 May 2009.

Submit your article to this journal $\sqsubset \pi$

Џ Article views: 3

Q View related articles $\square$ 
becaufe he generalifes his obfervations. The following are thofe which he has tranfmitted from Cumana refpecting the famous Peak de Teyde, called commonly the Peak of Teneriff: “ The Peak of Teyde, which rifes to the height of igo toifes, is an enormous bafaltic mountain that feems to reft on denfe and fecondary calcareous ftone. The latter is of the fame kind as that found with a great deal of flint at Cape Non in Africa, at Cadiz, in the: Channel, in Provence, and on which the bafaltes of Saint-Loup near Agde, and that of Portugal, reft. It is thus feen with what uniformity the globe is conftructed. The Azores, the Canaries, and the Cape Verd inles, appear to be a continuation of the bafalic rocks of Lifbon."

"T The waves thus carry with them, and cat on thore in Africa and Teneriff, granites, fyenites, and granitic micaceous fchift, which I have feen at Saini-Gethard. It is to be fuppofed that the high ridge of Mount Atlas, which exfends from the Eaft towards the coalts of Morceco, confifts of fuch roelss."

6: The bafaltes of which the Peak is conftrueted, is not only bafaltes containing foliaeeous and cryftallifed olivin and volcanie chryfolite, but particularly towards the top there are ftrata of the porpbyrofibiefer of Werner, or of another kind of porphyry with an obfiadian bafe. The porpbyrofebiefer is follated, fonorous, femi-tranfparent at the edges, has a very hard green bafe, and contains cryftals of vitreous feld-fpar.

[To be continued.]

XIII. Objervations on Ants, and on the Poifon of thefe Injects; witb fome Hints for deftroying tbem. By M. AmoUkeUX jun. M. D:*

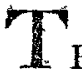

$\mathrm{H}$ thin example of forefight and economy, doês nờt, as has been believed; ftore up provifion; it is only laborious, and collects, indifcriminately, things that are eatable and others that are wot; the fortuer to fupply it with food for the moment, and

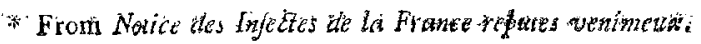


the latter to be employed as materials neceffary for fupporting fabterraneous galleries and for giving occupation to labourers ; for their fociety, like that of the bees, confilts of males and females, and a neutral fpecies; or individuals without fex: It is the latter that are charged with the internal labour, and the care of nourifhing the young. The labouring ants are diftinguifhed from the reft by being deftitute of wings; they enjoy alfo a longer life than the males or the females, and they often remain alone with the larvæ in the neft. Ants continue in a ftate of torpor during the winter; and it may thence be prefumed that the articles they ftore up do not confift. of food which they wifh to provide to afford them a fupply during periods of fcarcity. Their granaries are not filled with provifions, fince they ftore up, alơng with grains of corn, bits of ftraw and all other fmall articles which they can find. Naturalifts, therefore, have been miftaken refpecting this pretended forefight, by afcribing to a laborious infeet a manourte of which man alone is capable.

The ant is not accounted venomous, yet it is more fo than moft other infects. There arifes from its body an acid vapour which is not perceptible but when they are collected in a large number, as in an ant.hill, or when they are heared up in a box or bottle, \&c. For this reafon ants leave traces bet hind them, by a fort of fcorched appearance, on the grafs and plants over which they pafs and repafs in going back. wards and forwards from their nefts. Gardeners, therefore; have great reafon to wifh for the difcovery of fome certain means that might free them from thefe troublefome guefts; which fome have fuppofed to be tuffeful by having feen them attack the friall infects which injure the leaves of frinit-trees; and particularly thofe of the peach. Ants, indeed, are at: tracted by the melleots liquor thed by fome of thefe infeets, and which moiftens their bodies, but they do not on that account carry on war againft them; in concert with them they deftroy the plants and trees, on which they affemble in large bodies.

The ant pinches very ftrongly with its mouth, which is armed with jaws; it punetures alfo by means of a fing at its extremity, which is wanting in the males: it can do inVor. VII. 
jury, therefore, three different ways. Swammerdan lays that the jaws or forceps of the ant have on each fide feven points or fmall teeth; and Leuenhoek pretends that it emits from its fting fmall drops of a certain liquor which occafions pain. as is the cafe with that of the fcorpion. Probably it is nothing elfe than its acid liquor which is cautic.

This infect is very extraordinary, not only on account of its form, but on account of its fmall fize; and being fo commonly feen, it has not been examined with fufficient attention. Thofe who wilh to fee ants of a gigantic appearance, may infpect the figure given of one by Gundelius $\mathrm{Ab}$ Ach, who flattered himfelf that, in 1687 , he had invented a microfcope that magnified twice as much as any ever before confructed. The fame author has given the figure of a winged ant of the dimenfions of eleven inches.

We may ednfider ourfelves happy, that among the fmall number of fpecies of this infeet known in France, which Mr. Geoffroy makes to be only fix, there are none of thofe voracious and deftruetive kinds fo troublefome in the burning climates of Africa; in Egypt, and in South America. A fwarm of ants which have lodged in a hollow tree, iffue from it on its being in the leaft thaken, and, like a hower of fre, fall on the unhappy perfon expofed to their fury. One of our moft learned naturalifts, going along the banks of the Niger, found himfelf invefted by a fort of red ants which lodge in the icaco-tree. The punctures they made were fo venom* ous, fays he, that my face and hands were covered with blif. ters fimilar to thofe arifing from burning, the pain of which could be allayed by nothing but a heavy rain, which took place in the evening. The fame traveller was peftered in the ille of Gorée by another kind of white ants (termites) which gnaw and deftroy every thing that comes in their way.

Botanifts long ago obferved, that when the flowers of fuc. cary were thrown into an ant's neft, their blue colour was changed into red; which is, no doubt, common to the greater part of blue flowers. This phenomenon muit at firf have excited fome furprife, and it was explained, no doubt, according to the phyfieal knowledge of the period; but it was afterwards difcovered that this change of colour was owing 
to the acid liquor which the ants had thed upon it. This acid fpirit was carefully examined by feveral experiments, an account of which was publifhed in the Philofophical Tranfactions for the year 1670 . M. Tifcher appears to have been the firft who afcertained the nature of this acid, and this difcovery muft have appeared the more aftonifhing, as it was known that animals in general furnifled alkali and an urinous pirit.

After this, chemifts haftened to analyfe ants and the vapours exbaled from them. Homberg extracted from them, by diftillation, abundance of acid, and thowed it to the Academy of Sciences in 77 12. Margraf foon obtained the fame acid; but the learned Pruffian chemift confidered this acid only in regard to its relation and combinations with other chemical fubftances, and the folutions it is capable of effecting. This acid has a great refermblance to that of radical vinegar, though it does not refemble it in every thing: Neuman firft perceived an odorous effential oil, of a peculiar fmelf, which, however, occafions no burning fenfation on the tongue. Margraf obtained the fame fubtile oil, and another fat oi] fimilar to that of vegetables. M. Thouvenel drew from ants both thefe oils, and a particular extract; a refult of the mort complete analyfis that ever had been made of thefe infects.

The late M. Roux, the editor of the Journal de Medecine, paid attention alfo to this object, and by his curious experiments brought to light fome facts very little known. For example, if an ant-hill be opened, and a living frog be expofed in it, the animal will die in lefs than four or five minutes, though it has not been bit by the ants. M. Roux, being employed in collecting ants to fill a bottle, perceived in the evening that his fingers were famewhat hot, that they fwelled and became red; next day the epidermis feparated from the ain as if he had applied a veficatory, and his fingers became entirely peeled. It appears alfo, by M. Roux ${ }^{2} 8$ experiments, that the acid vapour of ants is capable of fuffocating them when they. are thut up in a bottle. This may fupply fome hints for. fitfling their deftructive colonies by carefully clofing up the apertures of ant-hills and heaping earth above them. M. Roux. mentions alfo an abfervation fimilar to his awn, which was 
communicated by Baron D'Holbach; he made at the fame time fome reflections on the nature of the poifon of ants, refpecting which he would not venture to give a decifive opinion. This prudent modefty in an able chemift may ferve us as a leffon.

Meffrs. Ardwiffon and Oerhne have alfo made a number of curious experiments on this acid, which they confider as a peculiar kind. It has been admitted into the new chemiftry under the name of the formicine: it is fronger than the vitriolic acid *, ferves for different combinations, and an ether may be obtained from it. M. Thouvenel, who prepared from it the formiate of potafh, experienced the fame effects from the volatile acid of ants as M. Roux; for, after having collected fome of thefe infects, large veficles full of ferous liquor were formed at the ends of lis fingers. This learned chemift made many experiments to afcertain the pature of the acid of ants, and they, all convinced him that it differs from the mineral acids as well as from fermented vegetable acid, and that it has every chemical relation to the microcofmic acid $\dagger$, \&c.

M. Cadet junior, and other chemifts, found that the volatile alkali deftroys ants and neutralifes their acid. This, therefore, may afford the means of being preferved from it, or of checking its action on the fkin. Olive oil produces the fame effect.

Medicine might perhaps derive more advantage than it has hitherto done from the volatile fpirit and oil of ants. A bath of ants has been prefcribed in cafes of the palfy. The wate or fpirit of magnanimity, and other pharmaceutic compofitions, are prepared from ants and their products. They might certainly be employed in veficatories.

To the above obfervations I fhall add the following fact, recorded in the Ephemerides of the curious of Nature for the year 1688 . which will prove the efficacy of ands as a revulifve remedy :-A fuller, who had been long tormented with a pain in his head, and tired of taking medicines with-

* The author, no doubt, means that it will decompofe forne of the ritriolic falts: in this fenfé many vegetable acids are ftronger than the vitriolic.-EDIT.

+ Phofphoric acid.

* Dec. 2, obj. 80 . 


\section{Infuence of Oxy gren on the Germination of Seeds.}

out receiving any benefit from them, refolved to difcontinue them, and to bear his fufferings with patience. One day, however, while collecting ants, his hands were excoriated by the acrid liquer of thefe infects, and he: was immediately freed from the pain in his head, which never afterwards returned.

XIV. Experiments refpecting the Infuence abicb Oxygen kas on the Germination of Seads. By. Mr. SAUs SuRE junior*.

M atmofpheric air have found, that feets expofed to water and pure azotic gas do not germinate; that, on the other hand. earbonic acid gas is formed, which mixes with the azotic: gas, and increafes the atmofphere of the plant. They obferved alfo; that wher oxygen gas was employed inftead of azot, carbonic acid gas was in the like mamer produced, but that the atmofphere was then leffened and the oxygen gas abforbed.

Dr. Rollot, in the courfe of his refearches refpecting the germination of barley, remarked, that the formation of fugar the grains of barley during the procefs of gewnination was the immediate confequence of the aetion of oxygem gas on the grains, and that, in every cafe where this aftion was fuppreffed; no fugar was formed. From this obfervation, as well as from the formation of carbonic acid gas in azotic and oxy:gen gas, he cencludes, that oxygen gas is in part abforbed by the barley, but that it in part forms with the carbon of the feeds earbonic aeid gas. "The higar which is formed immeWately after the germination is, according to thm, produced Wh the unien of oxygen gas with the llimy vegetable fermentible matter.

If the quantity of the earbonie acit gas formed in this man terbe lefs than that of the pxygen gas which has difappeared, is's probable thiat a part of the latter is abforbed by the grain,

From Schèrer's Algemeines Fournail der Cbemie, No. 7, for January sisoo. + It thould be Cruickfhank. 